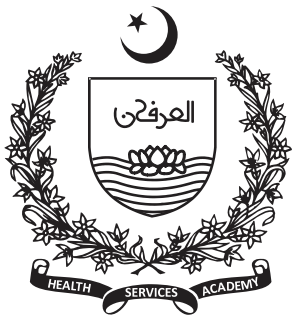

${ }^{1}$ Department of Sciences and Humanities, FAST National University of Computer and Emerging Science (NUCES), Karachi, Pakistan.

2Liaquat National Hospital and Medical College,

Karachi

${ }^{3}$ Department of Research, Research Mentor

Corresponding Author: Muhammad Irfan

Email:

irfanzafar892@gmail.com

\section{Indo-Pak Comparison and Forecasting of Covid-19 Epidemic: A Secondary Data Analysis}

\author{
Osama Ajaz ${ }^{1}$, Muhammad Irfan², Ayesha Siddiqa ${ }^{3}$, Muhammad Amjad ${ }^{1}$
}

\section{Abstract}

Background: The world has historically faced and recovered from many pandemics. The most recent global pandemic that the whole world is facing is Novel Coronavirus - Covid-19. The objective of current study is to compare and forecast COVID-19 trends for Pakistan and India.

Methods: The data set for this research is obtained from the World Health Organization (WHO) online repository (https://covid19.who.int/). The time period we have considered since the first corona related case and death were observed in both countries. This research paper analyzes corona related cases and deaths in Pakistan and India till $28^{\text {th }}$ February 2021, a total of 578,797 cases in Pakistan and 11,096,731 cases in India has been confirmed including 128,37 and 1,570,51 deaths respectively. The Auto-Regressive Integrated Moving Average (ARIMA) model is used to forecast the variables cumulative cases and deaths. It is simple to use and more predictive than any other regression model.

Results: Based on the current trend, the forecast graph reveals that the number of cumulative corona cases could reach 999,767 in Pakistan and 16,481,122 in India up to 31st December 2021.

Conclusion: This research found that corona related cumulative cases and deaths are on the rise in both countries. The pandemic situation in India is worse than in Pakistan nevertheless both countries are at high risk. There is a sudden increasing pattern in the number of corona related cases in both countries. Both governments must impose effective policies to control this pandemic

Keywords: ARIMA modeling, COVID-19, forecasting

\section{Introduction}

$\mathrm{T}$ he world has historically faced and recovered from many pandemics. The most recent global pandemic that the whole world is facing is Novel Coronavirus - Covid-19. The Virus has spread in almost every country at a rapid pace after initiating from China. (1) Although the virus has a low mortality rate, it is highly contagious due to which the response of the country dealing with the Covid-19 pandemic can be termed as a significant determinant of the consequences of this disease. (2) There are many articles for different countries around the world in regard to their responses to Covid-19. The current article has been aimed at sketching a comparison between the prevalent situation of Covid-19 in India and Pakistan which has resulted from their response to the pandemic.

Both the countries, India and Pakistan, can be regarded as being in the same phases of development 
and expenditure on healthcare with respect to their GDPs and they also have similar climatic condition. (3) India and Pakistan had their first cases within a month of each other as Pakistan had its first case on $26^{\text {th }}$ February 2020 in Karachi whereas India got its first case on $30^{\text {th }}$ January 2020 in Kerala. (3) Comparing the response of the two countries, it is known that India was quick to ban travels starting from early February and the country also issued the orders of a rapid lockdown in March for the purpose of containing the spread of Coronavirus. (4) In contrast, Pakistan responded slowly to the threat of Covid-19 as it's Prime Minister Imran Khan did not see the virus as a potential life-endangering threat and addressed the country downplaying the danger of Covid-19 stating that only old age people are affected by it. (5) He also encouraged the people to return to their work and mentioned that most cases of the virus can be resolved through self-quarantine. Nevertheless, realizing the danger of the virus, a lockdown in Pakistan was imposed in late March.

Moving on, it can be observed that the fast response of India to the Covid-19 pandemic was significantly effective in containing the danger and destruction of the virus as in May, the reported cases of India were one-third and mortality was almost half than that of Pakistan. (6) If a comparison is drawn between the stimulus package of India and Pakistan, it can be noted that the stimulus of Pakistan was much larger than that of India in terms of GDP percentage as Pakistan offered a stimulus of $2.5 \%$ of GDP and India offered a stimulus of $0.8 \%$ of GDP. (7) However, the economic situation of Pakistan has been estimated to be more affected than that of India as according to IMF (8), the economy of Pakistan is estimated to contract by $1.5 \%$ whereas India's economy is estimated to grow by $1.9 \%$ in the year 2020 . Hence, it can be stated by comparing both the countries that India dealt with the Covid-19 pandemic in a quick and effective manner while Pakistan was slow in taking actions due to which India's situation is comparatively that of Pakistan.

\section{Methodology}

\section{Data Collection Methodology}

The data set for this research is obtained from the World Health Organization (WHO) online repository (https://covid19.who.int/). The time period we have considered since the first corona related case and death were observed in both countries. The dataset for
Pakistan covered the time period from 28th February to 28th February 2021 and for India 30th January to 28th February 2021.

The following table 1 provides the summary of corona infected cases and deaths in both countries up to $28^{\text {th }}$ February 2021.

Table 1. Summary of corona infected cases and deaths in both countries (Jan. 2020 -- Feb. 2021)

\begin{tabular}{|c|c|c|c|c|}
\hline Country & $\begin{array}{c}\text { Max } \\
\text { Cases on } \\
\text { a single } \\
\text { day }\end{array}$ & $\begin{array}{c}\text { Max } \\
\text { Deaths on } \\
\text { a single } \\
\text { day }\end{array}$ & $\begin{array}{c}\text { Cumulativ } \\
\text { e cases }\end{array}$ & $\begin{array}{c}\text { Cumula } \\
\text { tive } \\
\text { deaths }\end{array}$ \\
\hline Pakistan & 13,709 & 313 & 578,797 & 128,37 \\
\hline India & 194,121 & 2,410 & $110,967,31$ & 157,051 \\
\hline
\end{tabular}

The highest number of individual cases $(13,709)$ was recorded on Sunday, 14th June in Pakistan. The individual cases keep on declining after this date. In India, the highest number of individual cases $(194,121)$ was recorded on Saturday, 12 September 2020 with an overall increasing trend. The highest number of individual deaths (313) per day was observed on Monday 21th November 2020 in Pakistan while 2,410 deaths were observed on Saturday 12 September 2020 in India. The above table 1 clearly reveals the fact that the number of cases and deaths in India keeps on high relative to Pakistan.

\section{ARIMA Model}

The R-package "Forecast" is used to forecast the number of corona infected cases and deaths in Pakistan and India. $\mathrm{R}$ is an open-source programming platform that is used for analysis and model development. $(9,10)$ The Auto-Regressive integrated moving average (ARIMA) model, available in the package, is run on our dataset. The analysis and results are given in the next sections. The ARIMA model is the mixture of autoregressive and moving average processes and is specified by three parameters $(\mathrm{p}, \mathrm{d}, \mathrm{q})$; where ' $\mathrm{p}$ ' represents the order for an autoregressive part, ' $\mathrm{d}$ ' represents the degree of integrated order difference $I(d)$, and ' $q$ ' represents the order for Moving average part.

The ARIMA model is represented by the following linear equation:

$$
\begin{gathered}
Y_{t}=\delta+\alpha_{1} y_{t-1}+\alpha_{2} y_{t-2}+\ldots+\alpha_{p} y_{t-p}+\beta_{1} e_{t-1}+\beta_{2} e_{t-2}+ \\
\ldots+\beta_{q} e_{t-q}+e_{t}(1)
\end{gathered}
$$


The above equation is assumed to be a non-seasonal time series model. See $(11,12)$ for seasonal components and other details about ARIMA modelling.

\section{Model Estimation and Analysis}

In this study, four separate ARIMA models are run for countries Pakistan and India. Two is for the number of corona infected cumulative cases and two for the number of coronae related cumulative deaths. Figure 1 below is the graph of confirmed cumulative corona cases in Pakistan and India for the period January 2020 to February 2021.

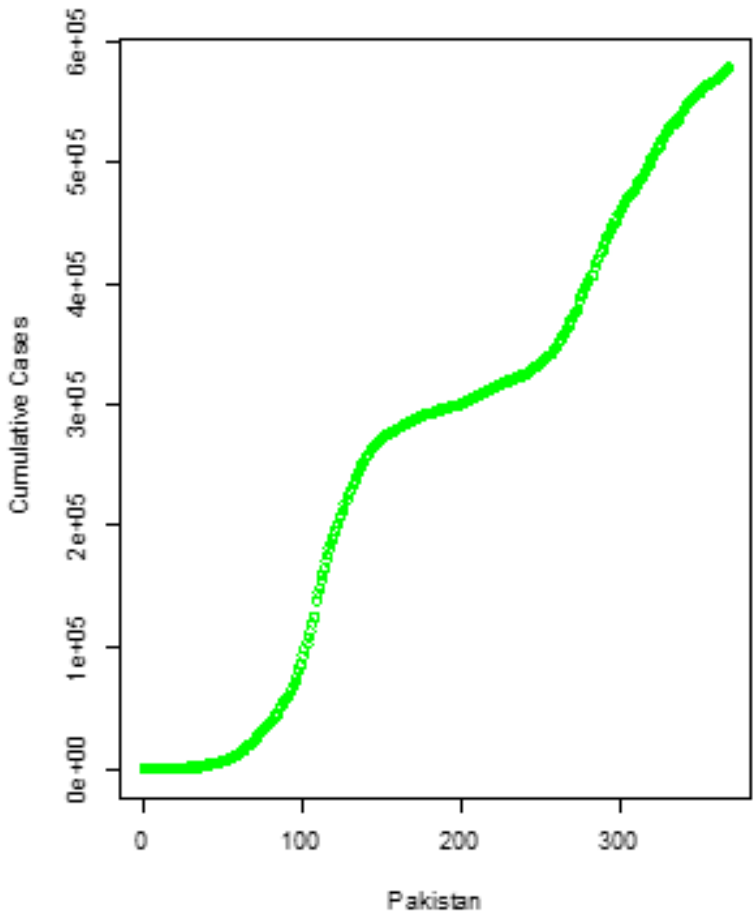

Figure 1. Number of corona infected cumulative cases in Pakistan and India

The above Fig. 1 represents the graph of cumulative corona infected cases in both countries. The corona infected cases are growing faster in India than Pakistan as clearly seen in the above figure. The same pattern is observed in the variable of death in both countries.

\section{Results}

The Forecast package in $\mathrm{R}$ is used to estimate the four ARIMA models for the number of corona related cumulative cases and deaths. Table 2 represents the best-fitted models based on minimum AIC and BIC criterion. Table 3 represents the estimates of accuracy parameters for the best-fitted models.

The 306 days forecast graph (1st March 2021 to 31st December 2021) of cumulative corona cases and death are given in Figure 2. The grey shaded area represents $80 \%$ confidence interval and white shaded area represents a $90 \%$ confidence interval in the figure. The forecast graph reveals that the number of cumulative corona cases could reach 999,767 in Pakistan and $16,481,122$ in India up to 31st December 2021. The number of cumulative deaths could reach 25,849 in Pakistan and 192,017 in India. The forecasted values are given in the table 4 below.

Table 2. Best ARIMA Model Estimates based on minimum AIC and BIC

\begin{tabular}{|c|c|c|c|c|c|c|c|c|}
\hline$\underset{\mathrm{e}}{\text { Variabl }}$ & Model & $\operatorname{AR}(\mathbf{1})$ & MA(1) & MA(2) & MA(3 & MA(4) & AIC & BIC \\
\hline $\begin{array}{l}\text { Cases } \\
\text { (Pak.) }\end{array}$ & $\begin{array}{l}\text { ARIMA } \\
(1,2,3)\end{array}$ & $\begin{array}{c}0.7770 \\
(0.0975)\end{array}$ & $\begin{array}{c}-1.9828 \\
(0.1140)\end{array}$ & $\begin{array}{c}1.3074 \\
(0.1730)\end{array}$ & $\begin{array}{l}-0.2527 \\
(0.0837)\end{array}$ & & 6292.39 & 6311.92 \\
\hline $\begin{array}{l}\text { Deaths } \\
\text { (Pak.) }\end{array}$ & $\begin{array}{c}\text { ARIMA } \\
(1,2,2)\end{array}$ & $\begin{array}{c}0.4703 \\
(0.2279)\end{array}$ & $\begin{array}{c}-1.5075 \\
(0.1980)\end{array}$ & $\begin{array}{c}0.6161 \\
(0.1616)\end{array}$ & & & 2549.48 & 2564.85 \\
\hline $\begin{array}{l}\text { Cases } \\
\text { (India) }\end{array}$ & $\begin{array}{c}\text { ARIMA } \\
(0,2,2)\end{array}$ & & $\begin{array}{l}-1.3179 \\
(0.0481)\end{array}$ & $\begin{array}{c}0.4456 \\
(0.0463)\end{array}$ & & & 760.31 & 772.24 \\
\hline $\begin{array}{l}\text { Deaths } \\
\text { (India) }\end{array}$ & $\begin{array}{c}\text { ARIMA } \\
(0,2,4)\end{array}$ & & $\begin{array}{l}-1.1528 \\
(0.0538)\end{array}$ & $\begin{array}{c}0.2291 \\
(0.0786)\end{array}$ & $\begin{array}{l}-0.0544 \\
(0.0766)\end{array}$ & $\begin{array}{l}0.1148 \\
(0.0515 \\
)^{2}\end{array}$ & 1457.53 & 1476.83 \\
\hline
\end{tabular}

Table 3. Model Accuracy Parameters

\begin{tabular}{|l|l|l|l|l|l|l|l|l|}
\hline $\begin{array}{l}\text { Variabl } \\
\mathbf{e}\end{array}$ & Model & ME & RMSE & MAE & MPE & MAPE & MASE & ACF1 \\
\hline $\begin{array}{c}\text { Cases } \\
\text { (Pak.) }\end{array}$ & $\begin{array}{c}\text { ARIM } \\
\text { A } \\
(1,2,3)\end{array}$ & 13.66375 & 971.6241 & 562.3845 & 0.8094183 & 1.811358 & $\begin{array}{c}0.35756 \\
86\end{array}$ & $\begin{array}{c}0.00978030 \\
5\end{array}$ \\
\hline $\begin{array}{c}\text { Deaths } \\
\text { (Pak.) }\end{array}$ & $\begin{array}{c}\text { ARIM } \\
\text { A } \\
(1,2,2)\end{array}$ & 0.1651041 & 27.49087 & 15.38458 & 0.4986578 & 1.265683 & $\begin{array}{c}0.41473 \\
05\end{array}$ & -0.01855311 \\
\hline $\begin{array}{c}\text { Cases } \\
\text { (India) }\end{array}$ & $\begin{array}{c}\text { ARIM } \\
\text { A } \\
(0,2,2)\end{array}$ & -2317.954 & 18688.18 & 9063.402 & 0.3903549 & 1.940577 & $\begin{array}{c}0.32262 \\
16\end{array}$ & 0.00709891 \\
\hline $\begin{array}{c}\text { Deaths } \\
\text { (India) }\end{array}$ & $\begin{array}{c}\text { ARIM } \\
\text { A } \\
(0,2,4)\end{array}$ & -21.95967 & 270.8032 & 137.7186 & 0.3364716 & 1.762918 & 0.30867 & 22 \\
\hline
\end{tabular}

Table 4. Cumulative Forecasted values from March 2021 to December 2021

\begin{tabular}{|c|c|c|c|c|}
\hline & \multicolumn{2}{|c|}{ India } & \multicolumn{2}{c|}{ Pakistan } \\
\hline Date & $\begin{array}{c}\text { Cumulativ } \\
\text { e Cases }\end{array}$ & $\begin{array}{c}\text { Cumulative } \\
\text { Deaths }\end{array}$ & $\begin{array}{c}\text { Cumulative } \\
\text { Cases }\end{array}$ & $\begin{array}{c}\text { Cumulative } \\
\text { Deaths }\end{array}$ \\
\hline 31-Mar-21 & $11,574,571$ & $16,0427.7$ & $62,1300.1$ & $14,102.22$ \\
\hline 30-Apr-21 & $12,052,311$ & $16,3744.4$ & $66,2781.6$ & $15,338.88$ \\
\hline
\end{tabular}




\begin{tabular}{|l|c|c|c|c|}
\hline 31-May-21 & $12,560,234$ & $16,7205.1$ & $70,5588.9$ & $16,629.8$ \\
\hline 30-Jun-21 & $13,065,792$ & $17,0586.5$ & $74,6963.5$ & $17,890.98$ \\
\hline 31-Jul-21 & $13,602,921$ & $17,4113.8$ & $78,9666.8$ & $19,205.82$ \\
\hline 31-Aug-21 & $14,155,247$ & 17,7675 & $83,2321.8$ & $20,531.86$ \\
\hline 30-Sep-21 & $14,704,450$ & $18,1153.4$ & $87,3557.3$ & $21,825.26$ \\
\hline 31-Oct-21 & $15,287,380$ & 18,4781 & $91,6124.4$ & $23,171.79$ \\
\hline 30-Nov-21 & $15,866,653$ & $188,323.6$ & 95,7279 & $24,484.13$ \\
\hline 31-Dec-21 & $16,481,122$ & $192,017.5$ & $999,766.5$ & $25,849.4$ \\
\hline
\end{tabular}

The standardized Q-Q plot and histograms for all models reflect normal curve distribution. The LjungBox test for all models indicates independence of residuals at $1 \%$ level of significance.

The accuracy of the forecast is assessed by the following formula:

$$
\text { Accuracy }=(\mathbf{1 0 0}-\mathrm{MAPE}) \%
$$

The best fitted models $\operatorname{ARIMA}(1,2,3), \operatorname{ARIMA}(1,2,2)$, $\operatorname{ARIMA}(0,2,2)$ and $\operatorname{ARIMA}(0,2,4)$ have accuracy of $98.188 \%, 98.734 \%, 98.059 \%$, and $98.237 \%$ respectively.

\section{Forecast Comparison Graph}
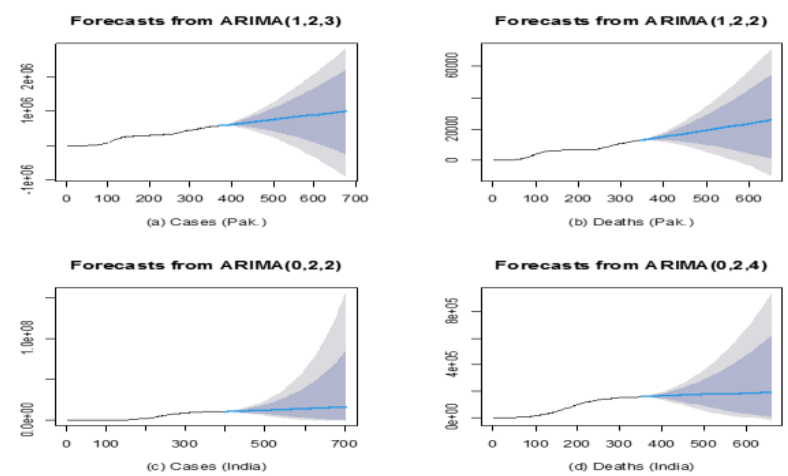

Figure 2. Forecast graphs for the number of cumulative corona cases and deaths for Pakistan and India.

\section{Discussion}

We used the WHO COVID-19 dataset for Pakistan and India. The purpose is to forecast the number of cumulative corona related cases and deaths in both countries. The AUTO ARIMA technique is used, which is available in the $\mathrm{R}$ package "forecast". The forecast model ARIMA is simple to use and more predictive than other regression models. It is due to the fact that the ARIMA model only considers the past lag values of dependent variables ${ }^{12}$ such that cumulative cases and deaths in this research.

Similar research has been done by many researchers. $(11,13,14)$ But most of the research forecasts cases and deaths for one to three months based on limited dataset. This study considers a dataset for almost one year and presents forecasts up to 31 ${ }^{\text {st }}$ December 2021. The all four forecasted models in this study are almost $98 \%$ accurate. In addition, very few studies are available that draw comparison between Pakistan and India for this corona pandemic. The two are important countries of Asia, have nuclear arms, and have fought four wars since 1947.

After the emergence of a number of cases and deaths due to coronavirus, both governments imposed a lockdown to keep people at home. All markets, marriage halls, restaurants, schools and universities were closed to avoid overcrowding and make lockdown effective. Schools and universities are encouraged to adopt e-learning methods. Several quarantine centres were established to treat corona infected patients. Besides the government's effort, several non-government organizations (NGOs) provided food and some amount door-to-door to needy families.

Currently, the citizens in both countries are being encouraged to take more protective measures and practice social distancing to control the COVID-19 pandemic. (15-17) Social media campaigns are being run to educate the public about this pandemic. Consequently, the spread of coronavirus is being expected to be decreased soon in the future. (16)

After this analysis, it is evident that COVID-19 pandemic situation in Pakistan is much better than India, nevertheless, both governments must take serious measures to cope with COVID-19 pandemic. Effective lockdown, self-isolation and public awareness are necessary to further control this pandemic.

\section{Conclusion}

This research found that corona related cumulative cases and deaths are on the rise in both countries. The pandemic situation in India is worse than in Pakistan nevertheless both countries are at high risk. There is a sudden increasing pattern in the number of corona related cases in both countries. There are several effective policies that both governments could put in place, such as smart lockdowns, work from home, 
subsidized pandemic-related products, or issuance of Corona relief funds.

\section{Grant Support \& Financial Disclosures: None}

Conflict of Interest: There is no conflict of interest Ethical approval: Ethical approval for the analyses presented in this was not sought as the paper is based on de-identified data provided by World Health Organization for the purposes of secondary analysis research.

\section{References}

1. Deshwal VK. COVID 19: A comparative study of Asian, European, American continent. Int J Sci Res Enginee Dev. 2020;3(2):436-40.

2. Das I, Bhattacharjee A. Trend analysis of Covid-19 cases in Indian subcontinent: Prediction comparison and psycho-social interventions. Indian Journal of Health \& Wellbeing. 2020 Jan 1;11.

3. Health spending less than one percent of GDP for decades [Internet]. Pakistantoday.com.pk. 2020 [cited 8 September 2020]. Available from: https://www.pakistantoday.com.pk/2019/07/01/healt h-spending-less-than-one-percent-of-gdp-for-decades/

4. Raza S, Rasheed MA, Rashid MK. Transmission Potential and Severity of COVID-19 in Pakistan.

5. Shah A, Choksi N. Did India handle Covid crisis better or Pakistan? The answer lies in these 4 tests [Internet]. ThePrint. 2020 [cited 8 September 2020]. Available from: https://theprint.in/opinion/did-india-handle-covidcrisis-better-or-pakistan/417098/

6. Pasha A. Should Pakistan instate a travel ban against coronavirus emergent regions? I The Express Tribune [Internet]. The Express Tribune. 2020 [cited 8 September 2020]. Available from: https://tribune.com.pk/article/94617/shouldpakistan-instate-a-travel-ban-against-coronavirusemergent-regions

7. NEWS, B. and News, I., 2020. IMF India GDP Forecast: IMF Projects India's Growth Rate At 1.9\% In 2020, Forecasts Global Recession Due To Covid-19 India Business News - Times Of India. [online] The Times of India. Available at: <https://timesofindia.indiatimes.com/business/indiabusiness/imf-projects-indias-growth-rate-at-1-9-in2020-forecasts-global-recession-due-to-covid19/articleshow/75142899.cms> [Accessed 8 September 2020].

8. Pakistan records highest single day spike in COVID-19 infections [Internet]. The Economic Times. 2020 [cited 8 September 2020]. Available from: https://economictimes.indiatimes.com/news/internati onal/world-news/pakistan-records-highest-single-dayspike-in-covid-19-infections/articleshow/75507645.cms

9. Hyndman R, Athanasopoulos G, Bergmeir C, Caceres G, Chhay L, O'Hara-Wild M, Petropoulos F, Razbash S, Wang E, Yasmeen F (2020). forecast: Forecasting functions for time series and linear models. R package version 8.13, https://pkg.robjhyndman.com/forecast/.

10. HYNDMAN, Rob J.; KHANDAKAR, Yeasmin. Automatic Time Series Forecasting: The forecast Package for R. Journal of Statistical Software, [S.1.], v. 27, Issue 3, p. 1 - 22, july 2008. ISSN 1548-7660. Available at: <https://www.jstatsoft.org/v027/i03>. Date accessed: 20 oct. 2020 doi:http://dx.doi.org/10.18637/jss.v027.i03.

11. N. Kumar and S. Susan, "COVID-19 Pandemic Prediction using Time Series Forecasting Models," 2020 11th International Conference on Computing, Communication and Networking Technologies (ICCCNT), Kharagpur, India, 2020, pp. 1-7, doi: 10.1109/ICCCNT49239.2020.9225319.

12. Box G. (2013) Box and Jenkins: Time Series Analysis, Forecasting and Control. In: A Very British Affair. Palgrave Advanced Texts in Econometrics. Palgrave Macmillan, London. https://doi.org/10.1057/9781137291264_6

13. Ganiny, S., Nisar, O. Mathematical modeling and a month ahead forecast of the coronavirus disease 2019 (COVID-19) pandemic: an Indian scenario. Model. Earth Syst. Environ. 7, 29-40 (2021). https://doi.org/10.1007/s40808-020-01080-6

14. K.E. ArunKumar, Dinesh V. Kalaga, Ch. Mohan Sai Kumar, Govinda Chilkoor, Masahiro Kawaji, Timothy M. Brenza, Forecasting the dynamics of cumulative COVID-19 cases (confirmed, recovered and deaths) for top-16 countries using statistical machine learning models: Auto-Regressive Integrated Moving Average (ARIMA) and Seasonal Auto-Regressive Integrated Moving Average (SARIMA), Applied Soft Computing, Volume 103, 2021, 107161, ISSN 1568-4946, https://doi.org/10.1016/j.asoc.2021.107161

15. Ali MY, Bhatti R. COVID-19 (Coronavirus) Pandemic: Information Sources Channels for Public Health Awareness. Asia Pacific Journal of Public Health. 2020;32(4):168-169. doi:10.1177/1010539520927261

16. Patrikar SR, Kotwal A, Bhatti VK, et al. Incubation Period and Reproduction Number for Novel Coronavirus 2019 (COVID-19) Infections in India. Asia Pacific Journal of Public Health. August 2020. doi:10.1177/1010539520956427

17. Abid K, Bari YA, Younas M, Tahir Javaid S, Imran A. Progress of COVID-19 Epidemic in Pakistan. Asia Pacific Journal of Public Health. 2020;32(4):154-156. doi:10.1177/1010539520927259 